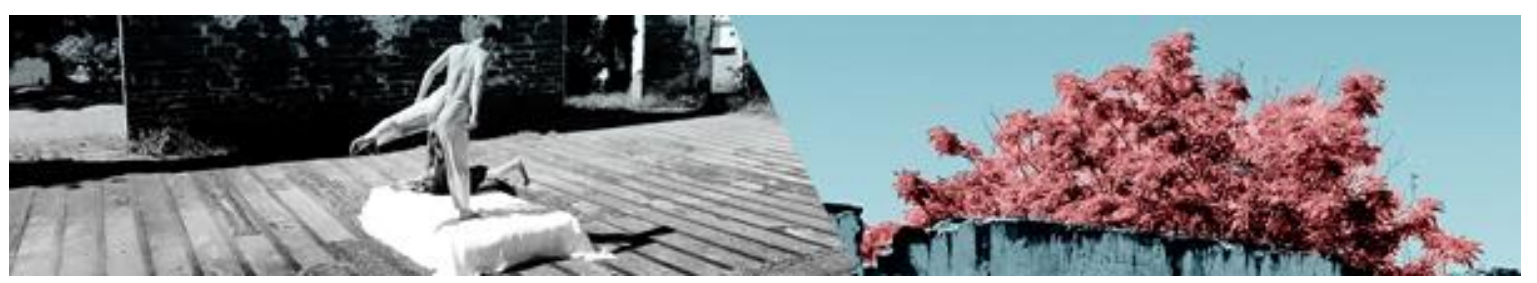

\title{
MOMENTOS-CHARNEIRAS E MEMÓRIAS MUSICAIS: ENCONTROS E CONEXÕES NAS NARRATIVAS DE ACADÊMICOS EM DANÇA
}

\author{
Ziliane Lima de Oliveira Teixeira ${ }^{1}$ \\ Ana Lúcia de Marques e Louro-Hettwer ${ }^{2}$
}

\begin{abstract}
Resumo: Neste artigo é relatada uma pesquisa realizada na disciplina de Música para os cursos de bacharelado e licenciatura em Dança de uma universidade do Sul do Brasil. A ementa proposta para a disciplina é ampliada de estudos de ritmo e compassos para incluir também narrativas (auto)biográficas dos alunos. São feitas aproximações com Josso $(1988,2004)$ ao convidar os alunos a falarem e escreverem sobre momentos importantes que envolveram música em suas vidas, bem como da perspectiva da Espiritualidade e Artes. São analisados cinco trechos das narrativas por escrito. Relatos dos alunos colocam que esta atividade de narrar uma memória musical despertou diversos sentimentos, proporcionando conhecer uns aos outros e reconhecerem a si mesmo.

Palavras-chave: Momentos-charneira; Memórias musicais; Dança.
\end{abstract}

\section{HINGE-MOMENT AND MUSICAL MEMOIRS: FINDINGS AND CONECTIONS IN NARRATIVES FROM DANCE ACADEMICAL STUDENTS}

\begin{abstract}
This article reports a research in the academic discipline of Music for undergraduate and graduate courses in dance at a University in South Brazil. The syllabus for the course assignment is an enlarged study of rhythms and beats to include students' narrative (auto)biographical. The approach was made through Josso $(1988,2004)$ to invite students to speak and write on important moments Involving music in their lives as well as Spirituality and Arts. Five stretches of narrative writings were analyzed. The stories of the students pointed that the activity of narrating a musical memory elicited many feelings, allowing them known to each other and also recognize themselves.

Key words: Hinge-moment; Musical momoirs; Dance.
\end{abstract}

\section{MEMÓRIAS MUSICAIS: MARCO TEÓRICO METODOLÓGICO}

Por que narrativas sobre memórias musicais em aulas para os cursos de Dança? Qual a importância das narrativas nessas aulas? Respondo com outra

\footnotetext{
${ }^{1}$ Ziliane Lima de Oliveira Teixeira - Professora Adjunta do Curso de Licenciatura em Música da Universidade Federal de Alagoas (UFAL). Doutora em Educação (Educação e Artes - 2016) pela Universidade Federal de Santa Maria (UFSM), Mestre em Música pela Universidade de Aveiro (2011) e Bacharela em Música pela UFSM (2007).

2 Ana Lúcia de Marques e Louro-Hettwer - Doutora em Música pela Universidade Federal do Rio Grande do Sul, é Professora Associada do Programa de Pós-Graduação em Educação e dos Cursos de Música da Universidade Federal de Santa Maria. Líder do Grupo de Pesquisas NarraMus.
}

TEIXEIRA, Ziliane Lima de Oliveira; LOURO-HETTWER, Ana Lúcia de Marques. Momentoscharneiras e memórias musicais: encontros e conexões nas narrativas de acadêmicos em dança. Revista da FUNDARTE, Montenegro, p.506-527, ano 19, ํㅜ 37, Janeiro/Março.

Disponível em: http://.seer.fundarte.rs.gov.br/index.php/RevistadaFundarte/index> 30 de março de 2019. 


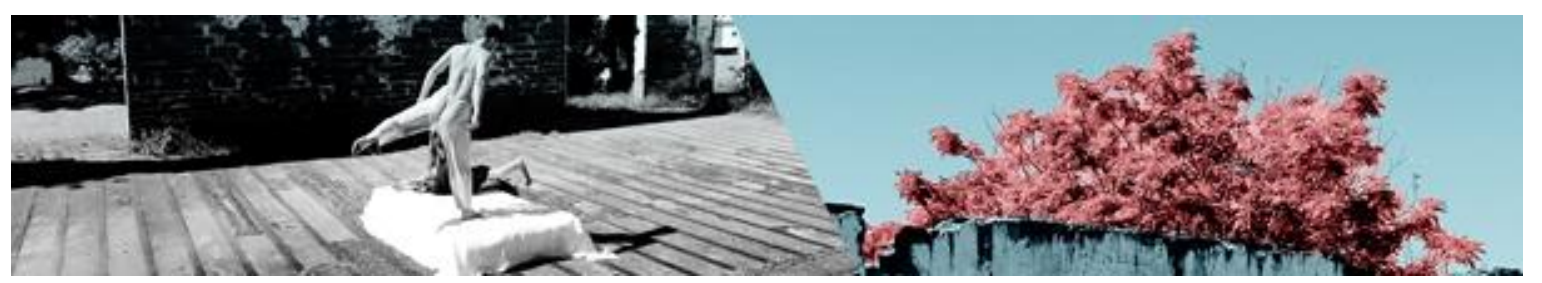

pergunta: Por que a aula de música para acadêmicos de dança não pode ir além do que consta na ementa e trabalhar somente ritmos e compassos?

Pensando nestas perguntas e buscando respostas, comecei ${ }^{3}$ a desenvolver uma pesquisa sobre memórias musicais com acadêmicos dos cursos de Bacharelado e Licenciatura em Dança em uma universidade do Sul do Brasil. Bowman (2006) também nos questiona o porquê e os limites da narrativa. Eu poderia dar outro tipo de aula para os alunos de dança. Então, por que narrativas? De acordo com este autor, a narrativa se torna uma resposta para a formação de um professor (dançarino) capaz de refletir sobre si mesmo.

Bresler (2006) mapeia o percurso conceitual do termo narrativa, focalizando interpretações diferentes em várias disciplinas ao longo dos últimos 50 anos, e propõe o conceito de embodied narrative, sugerindo que "a investigação narrativa em ciências sociais [...] é fundamentada em sensibilidades auditivas, sinestésicas e estéticas" (p. 23). O exercício de buscar uma memória musical passa por estas experiências auditivas, sinestésicas e estéticas relatadas pela autora, que ainda nos adverte que, apesar das limitações das "metáforas musicais", estas se tornam interessantes para refletir junto com a música, pois neste caso, as memórias musicais não são utilizadas como ilustração, e sim como problematização, sendo dispositivos para encontros com outros lugares e momentos.

Neste mesmo sentido, Stauffer e Barrett (2009) contam sobre aulas de músicas e as relações com músicas, sendo isto uma forma de preservar as experiências; abordando a importância de se narrar para refletir a experiência com música, já que desta maneira podemos tornar nossa vivência em experiência.

3 Este artigo é escrito na primeira pessoa do singular. Esta pesquisa foi realizada pela primeira autora que a desenvolveu enquanto docente da disciplina Música para alunos de Dança. A autora assume a problematização das suas vivências pessoais como parte do processo de pesquisa, o que conduz à escolha da conjugação na primeira pessoa do singular. No entanto, este artigo teve a participação direta da segunda autora, não como protagonista-pesquisadora, mas como orientadora e contraponto de leitura e discussão teórica, muitas vezes contribuindo com partes da escrita do texto, o que nos fez parecer relevante incluí-la também como autora.

TEIXEIRA, Ziliane Lima de Oliveira; LOURO-HETTWER, Ana Lúcia de Marques. Momentoscharneiras e memórias musicais: encontros e conexões nas narrativas de acadêmicos em dança. Revista da FUNDARTE, Montenegro, p.506-527, ano 19, no 37, Janeiro/Março.

Disponível em: http://.seer.fundarte.rs.gov.br/index.php/RevistadaFundarte/index> 30 de março de 2019. 


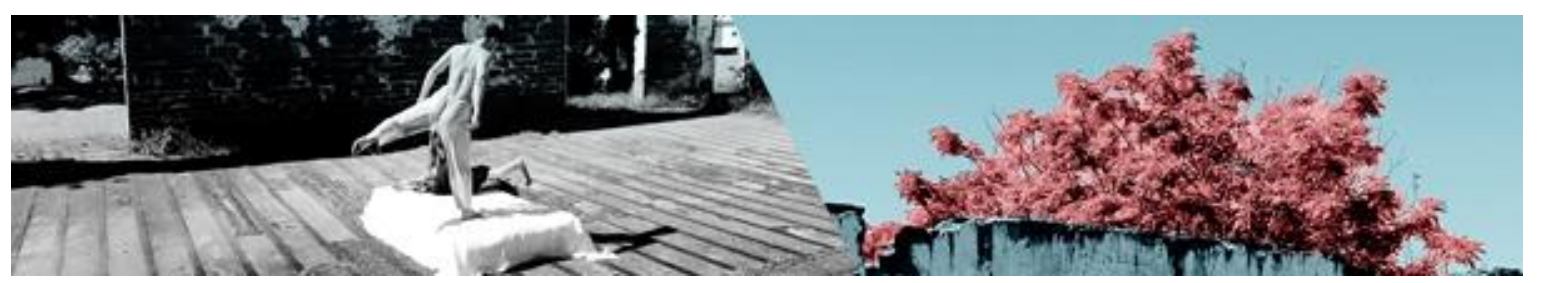

Maria Cecília Torres foi uma das primeiras autoras brasileiras que realizou pesquisa utilizando as memórias musicais. Torres (2008) buscou refletir a partir das memórias de alunas de um curso de Pedagogia onde o foco do trabalho era "conhecer o gosto musical deste grupo através de narrativas orais e escritas" ( $p$. 237) bem como encontrar a "relação entre as lembranças musicais e suas práticas e crenças pedagógicas" (p. 237). As narrativas escritas pelas alunas são chamadas por Torres de "autobiografias musicais" (p. 239) nas quais elas descrevem fatos, cenas, músicas e momentos de entrelaçamentos pessoais e musicais.

\section{LINEARIDADE OU FRAGMENTAÇÃO}

Ao escrever este texto pensei primeiramente sobre a questão narrativa: contar uma história. No entanto, ao buscar o relato da pesquisa baseada em memórias musicais, vislumbrei logo a necessidade de uma não linearidade. As memórias, ao evocar o passado, projetam a reflexão do presente para o futuro, algo já muito discutido na pesquisa (auto)biográfica. A pergunta se tornou: como escrever este texto para que fosse ao mesmo tempo relatório de pesquisa, reflexão pessoal, revisão dos autores, relato sobre as aulas da disciplina e diálogo com as memórias dos alunos? Lembrei-me de uma leitura que fiz de Dossê:

A originalidade dessa tentativa biográfica deve-se, sobretudo, à recusa dos autores de recorrer a um relato histórico clássico, como base em seu reconhecimento dos arquivos. Repele também outra solução, a de redigir uma obra segundo o modelo da coleção dos "Archives", que constituía em reunir e apresentar tematicamente o material bruto, seguido de um comentário especializado. Ou, sem nenhuma intenção de estimular outras tentativas, lembra mais uma montagem cinematográfica a maneira de JeanLuc Godard: emenda enunciados discursivos do mesmo modo que o cineasta liga imagens em planos de sequências, fragmentando determinadas séries e recompondo outras. (DOSSÊ, 2009, p.275).

Fragmentar é recompor, como coloca Dossê. Assim, este texto se divide em diversos fragmentos, a partir daqui organizado em três partes: Contextos e Revisão da Literatura, Análise e Transversalização de dados e apontamentos finais.

TEIXEIRA, Ziliane Lima de Oliveira; LOURO-HETTWER, Ana Lúcia de Marques. Momentoscharneiras e memórias musicais: encontros e conexões nas narrativas de acadêmicos em dança. Revista da FUNDARTE, Montenegro, p.506-527, ano 19, ํㅜ 37, Janeiro/Março.

Disponível em: http://.seer.fundarte.rs.gov.br/index.php/RevistadaFundarte/index> 30 de março de 2019. 


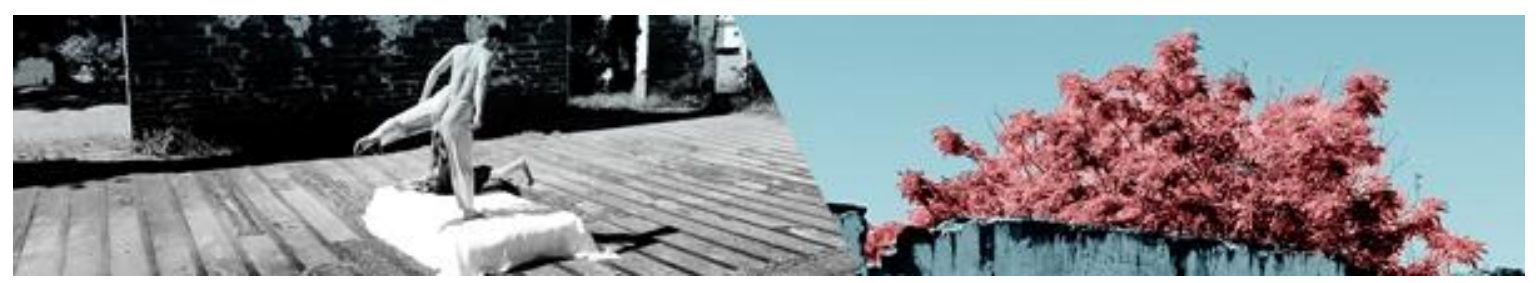

Considero o primeiro fragmento que inicia o texto como um marco teóricometodológico. Assim, a revisão da literatura se mescla à narrativa dos contextos; na análise de dados busco pontuar caminhos ao mesmo tempo em que dialogo com as memórias musicais dos meus alunos, e na transversalização de dados e apontamentos finais apresento algumas interconexões dos conceitos com os dados, pontuando considerações sobre a pesquisa.

\section{CONTEXTOS E REVISÃO DA LITERATURA}

Nas pesquisas realizadas dentro do Grupo de Pesquisa de que faço parte, buscamos refletir sobre fenômenos da Educação Musical através das narrativas de si, a partir de entrevistas de história oral, diários de aulas e outros escritos (auto)biográficos. Durante o ano de 2012 cursei, na mesma instituição onde realizei a pesquisa, a disciplina de Docência Orientada ${ }^{4}$ e duas Disciplinas Complementares de Graduação no curso de Licenciatura em Música: "a 'narrativa de si' na pesquisa em Educação Musical" no primeiro semestre e a "Pesquisa em Música a partir da 'experiência de si'” no segundo semestre. Essas disciplinas tinham como objetivo problematizar as experiências dos alunos para auxiliá-los em seus processos de pesquisa na área de Educação Musical.

Propusemos, portanto, aos alunos que escolhessem uma música significativa para suas vidas e a associassem a sua reflexão sobre a temática de pesquisa que estavam estudando ou pretendiam estudar. A partir destas narrativas, realizamos algumas pesquisas que já foram publicadas em congressos e revistas científicas.

Diferentemente de um processo mais tradicional de trabalho com os temas de pesquisa, nas investigações realizadas com estes alunos, a temática era trabalhada a partir de uma reflexão sobre as histórias de vidas dos participantes. No entanto, nestas lembranças dos alunos, "as músicas não são tratadas como mera ilustração, mas são catalizadoras de subjetividades que então são narradas e, através desses

\footnotetext{
${ }^{4}$ Disciplina ofertada no curso Doutorado em Educação onde o aluno acompanha um professor em sala de aula, ministrando algumas aulas ao longo do semestre.

TEIXEIRA, Ziliane Lima de Oliveira; LOURO-HETTWER, Ana Lúcia de Marques. Momentoscharneiras e memórias musicais: encontros e conexões nas narrativas de acadêmicos em dança. Revista da FUNDARTE, Montenegro, p.506-527, ano 19, ํㅜ 37, Janeiro/Março.

Disponível em: http://.seer.fundarte.rs.gov.br/index.php/RevistadaFundarte/index> 30 de março de 2019.
} 


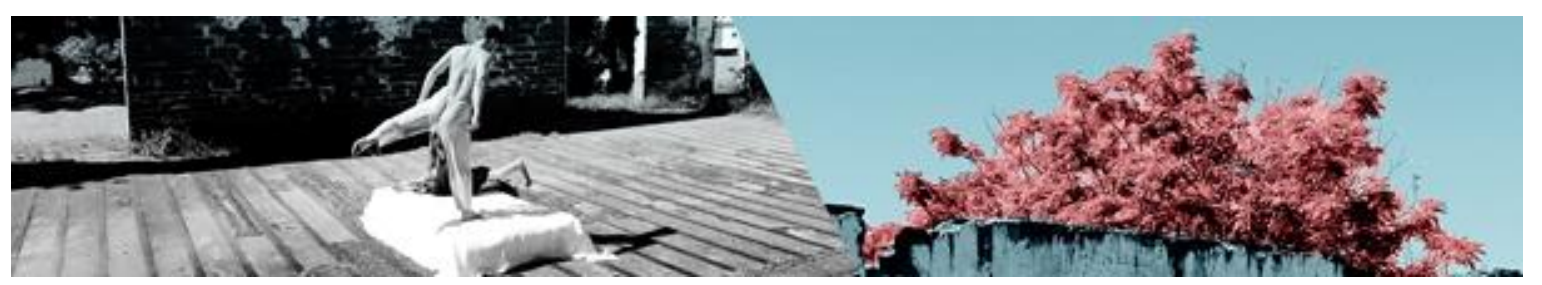

textos, refletidas pelos alunos da disciplina na qual foi realizada" (LOURO; TEIXEIRA, p.20, 2013).

Nessa direção as músicas se aproximam do uso de fotografias. Da mesma forma que em outras pesquisas são utilizadas as fotografias (ALVES, 2010; CONNELLY; CLANDININ; HE, 1997; OLIVEIRA et al, 2004), as músicas servem como catalizadoras das memórias. Desta forma, ao falar sobre músicas e seus aprendizados, os alunos evocam lembranças de suas vidas, e trazem este contexto do vivido para as discussões sobre ensino e pesquisa em Educação Musical que são feitos nas disciplinas.

Falar dos aprendizados com música é falar do tempo em que muitas vezes os alunos eram crianças e adolescentes, desafiados a aprender algo novo e movidos por curiosidades emergentes. Muitos dos estudantes das disciplinas de Educação Musical localizam este mesmo desafio e curiosidade nos seus modos de vivenciar a docência em música, e nos caminhos que traçam para trilhar seus direcionamentos nas pesquisas que procuram realizar. Desta maneira, em um dos trabalhos finais propostos (analisado enquanto narrativa de si por escrito para a pesquisa) os alunos relacionam a memória de um aprendizado musical em torno de uma música específica, sua prática pedagógica e a pesquisa que estão fazendo ou pretendem fazer. (LOURO 2013). Este encaminhamento metodológico de ensino e pesquisa serviu de inspiração ao que posteriormente realizei junto aos alunos da dança ${ }^{5}$.

\section{Aulas para a dança?}

Quando fiz o concurso para professor substituto de Flauta Transversal nesta universidade, jamais imaginei que daria aula para o estreante Curso de Dança nesta instituição. Fui informada que os cursos de Dança (Bacharelado e Licenciatura) tinham dois semestres da disciplina de Música (I e II) e que eu as assumiria. No

\footnotetext{
${ }^{5}$ Uma pesquisa com dados de outra turma também do Curso de Dança foi publicado pela Revista Educere et Educare: TEIXEIRA, Ziliane Lima de Oliveira; LOURO, Ana Lúcia. Memórias musicais, espiritualidade nas artes e a "busca da felicidade": uma pesquisa-formação com acadêmicos de dança. Revista Educere et Educare, v. 13, n. 28, p. 1-19, 2018.
}

TEIXEIRA, Ziliane Lima de Oliveira; LOURO-HETTWER, Ana Lúcia de Marques. Momentoscharneiras e memórias musicais: encontros e conexões nas narrativas de acadêmicos em dança. Revista da FUNDARTE, Montenegro, p.506-527, ano 19, ํㅜ 37, Janeiro/Março.

Disponível em: http://.seer.fundarte.rs.gov.br/index.php/RevistadaFundarte/index> 30 de março de 2019. 


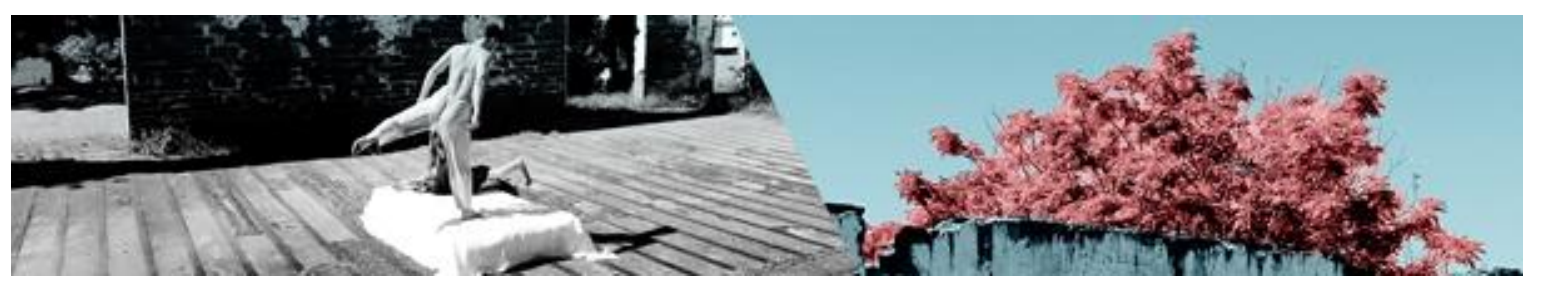

momento achei interessante o desafio e fui conversar com o professor que estava ministrando a disciplina até eu ser nomeada nesse concurso. Me falou com muita animação a respeito dos alunos da dança, e me contou o que estava trabalhando e como a classe estava respondendo. Senti-me extremamente eufórica em trabalhar com eles, enfrentando esse novo desafio.

Em meio à preparação dos exercícios de ritmo, que eram o foco da disciplina Música I, minha orientadora de Doutorado (a segunda autora desta comunicação) sugeriu que fizesse com os alunos um exercício sobre memórias musicais, semelhante a um trabalho que havíamos feito nas Disciplinas Complementares de Graduação anteriores no Curso de Música. Portanto, propus aos alunos, já no primeiro dia de aula, que eles trouxessem músicas ligadas às histórias de vida deles, ao envolvimento com a dança; uma música que tivesse marcado algum momento da vida deles.

A cada aula era uma nova surpresa e uma nova emoção. Lembranças de infância, lembranças de um momento em que se desejava fazer um curso superior em Dança que ainda não havia nesta cidade, lembranças de uma coreografia premiada, lembranças de um treinador que se tornou o grande amor, lembranças da última coreografia na cidade natal - hoje tão longe - lembranças do ensino médio, lembranças de um grande amigo e parceiro de dança que faleceu, lembranças das Danças Tradicionalistas Gaúchas, lembranças do desejo de fazer da dança a profissão, lembranças da coragem para prestar o vestibular para Dança depois dos 40 anos de idade, da vontade de ser feliz! Histórias compartilhadas, memórias, emoções... As lágrimas brotavam nos rostos de quem contava a história e de quem ouvia a música, misturando-se com sorrisos e reflexões.

\section{Um interlúdio sobre minha metodologia de aula de música para dança e espiritualidade}

TEIXEIRA, Ziliane Lima de Oliveira; LOURO-HETTWER, Ana Lúcia de Marques. Momentoscharneiras e memórias musicais: encontros e conexões nas narrativas de acadêmicos em dança. Revista da FUNDARTE, Montenegro, p.506-527, ano 19, no 37, Janeiro/Março.

Disponível em: http://.seer.fundarte.rs.gov.br/index.php/RevistadaFundarte/index> 30 de março de 2019. 


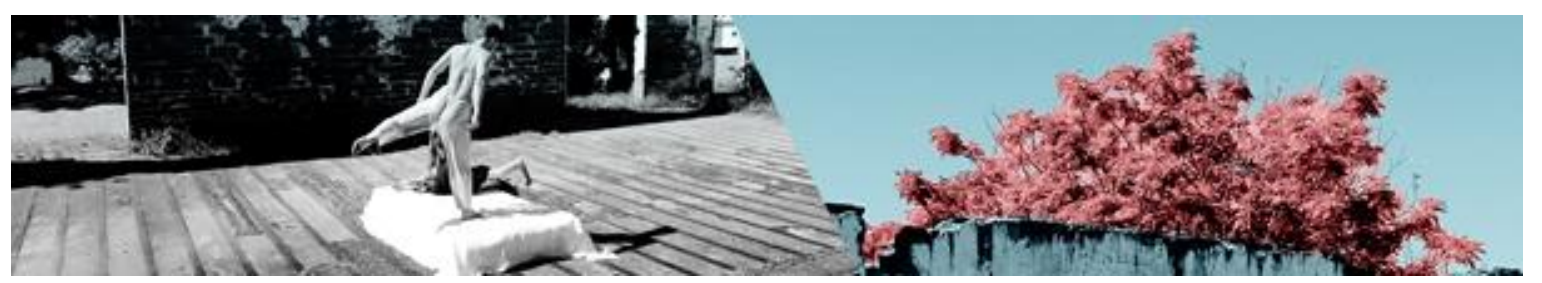

As palavras que escrevi acima despertam uma possível curiosidade pelas histórias que foram narradas pelos acadêmicos. Porém, antes de apresentá-las e analisá-las, gostaria de contextualizar com outros pressupostos teóricos dessa pesquisa.

Sendo a área de Dança ainda bastante recente para mim enquanto artista, pesquisadora e professora ligada à área de Música, um texto em particular me chamou a atenção, pois coloca o ensino de dança na mesma perspectiva de aproximação entre artes e Espiritualidade com que tomo o ensino de Música.

Snowber (2007) define espiritualidade como algo que "não se limita a um aspecto do ser humano. Ela inclui buscar e tatear, orar e celebrar, o vazio e a completude, a alegria e a lamentação" (p.1433). Além disso, enfatiza a habilidade de se estabelecer "conexões com a vida interior, o outro, o mundo natural, para o numinoso, mas acima de tudo para nós mesmos" (p. 1450). Neste sentido esta autora considera o corpo como "espaço sagrado onde se vive as alegrias e tristezas da vida" (p.1450). Ela aponta os desdobramentos dessa abordagem com uma pergunta:

O que significaria estar atento ao impulso de responder as ponderações sobre uma dimensão espiritual, seja para um educador, pesquisador, bailarino, ou aquele que se encontra em busca dos sentidos da vida? Eu convido você a considerar tanto o corpo como a arte da dança como se fosse um jardim no qual você se move, no qual tanto o dom da gravidade como da levitação podem impulsionar a alma (p.1452).

Em relação à Espiritualidade e à Música, Boyce-Tillman (2007) realça a importância das narrativas para si, e sua abordagem se aproxima "com a natureza da espiritualidade musical, com base em experiências narradas de música por uma variedade de pessoas envolvidas em musicar ${ }^{\prime \prime}$ (p.1406).

\footnotetext{
${ }^{6}$ Este termo foi cunhado pelo musicólogo e Educador musical Cristopher Small. Ele diz: "Eu encontrei-me tentando encontrar uma maneira de expressar essa ideia [...], em primeiro lugar, que a essência da música está na performance, e segundo que a performance é um encontro em que os seres humanos se relacionam entre si. Então eu descobri que eu estava usando a palavra música, e não como um substantivo, mas como verbo [...] Eu ofereço a você agora, o verbo musicar com o seu particípio presente musicando" (em inglês musicking).
}

TEIXEIRA, Ziliane Lima de Oliveira; LOURO-HETTWER, Ana Lúcia de Marques. Momentoscharneiras e memórias musicais: encontros e conexões nas narrativas de acadêmicos em dança. Revista da FUNDARTE, Montenegro, p.506-527, ano 19, no 37, Janeiro/Março.

Disponível em: http://.seer.fundarte.rs.gov.br/index.php/RevistadaFundarte/index> 30 de março de 2019. 


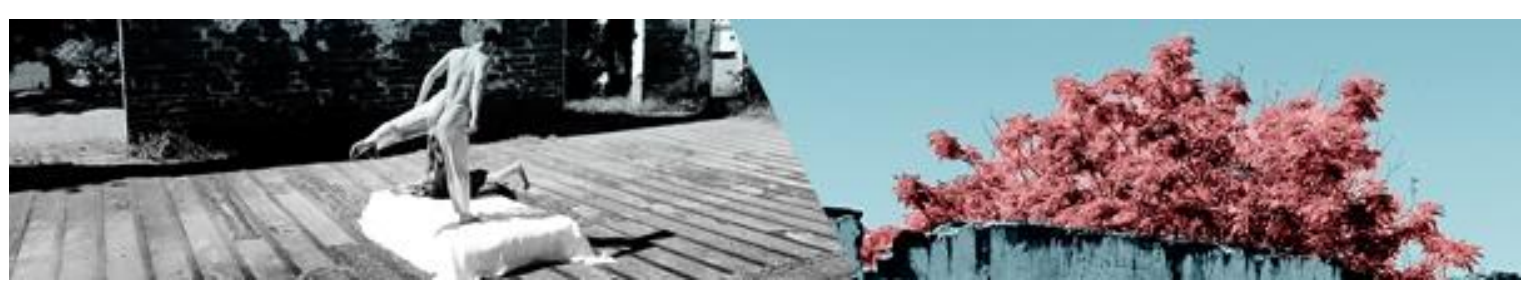

Esta mesma autora destaca a possibilidade de conjugar na experiência musical as dimensões de valores, materiais, construção e expressão. Boyce-Tillman (2007) acredita que:

Para conseguir um "ajuste" que é susceptível de produzir uma experiência espiritual no experimentador, tem que haver congruência suficiente entre os vários domínios de experiência (pelo menos dois, sugiro) entre o experiente e o experiente e a experiência. Quanto melhor o ajuste entre as diversas áreas na peça como percebido pela experiência, mais eles são como entrar no domínio espiritual indescritível através do encontro com o Outro na música. Este será afetado pelas palavras e experiências em torno do evento e fatores culturais (p. 1416).

Este modelo pode ser melhor visualizado nos gráficos abaixo apresentados por Boyce-Tillman (2007), nas figuras 1 e 2.

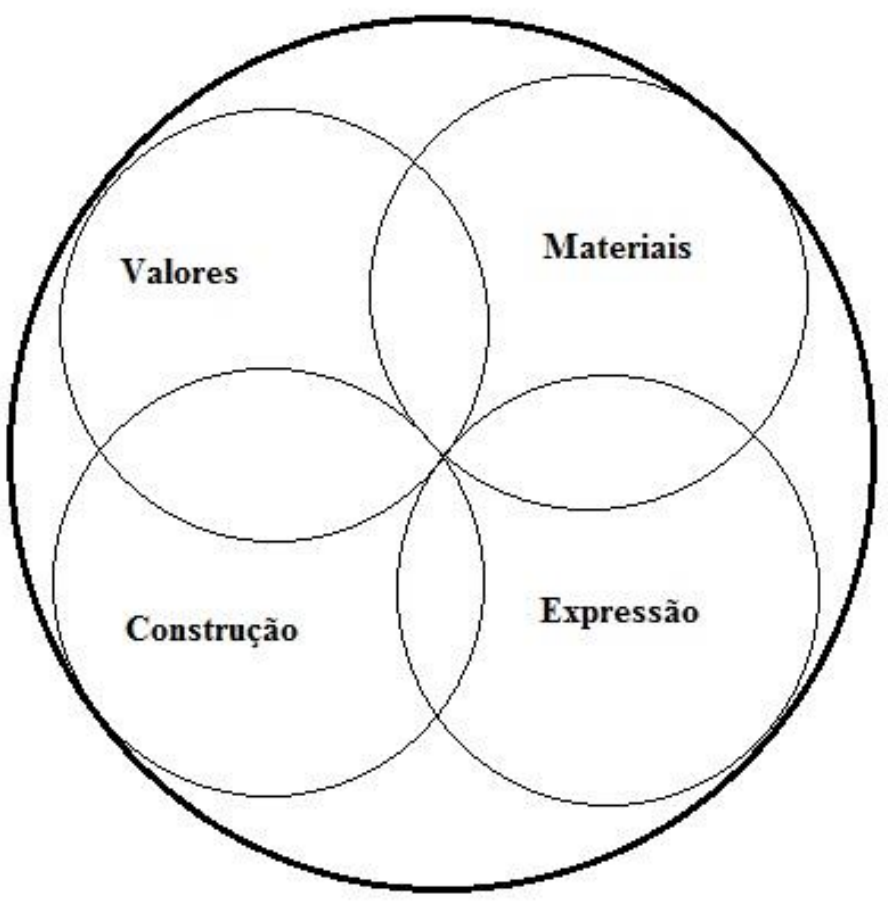

Figura 1: A experiência espiritual completa. Adaptado e traduzido de Boyce-Tillman (2007, p. 1415).

TEIXEIRA, Ziliane Lima de Oliveira; LOURO-HETTWER, Ana Lúcia de Marques. Momentoscharneiras e memórias musicais: encontros e conexões nas narrativas de acadêmicos em dança. Revista da FUNDARTE, Montenegro, p.506-527, ano 19, ํㅜ 37, Janeiro/Março.

Disponível em: http://.seer.fundarte.rs.gov.br/index.php/RevistadaFundarte/index> 30 de março de 2019. 

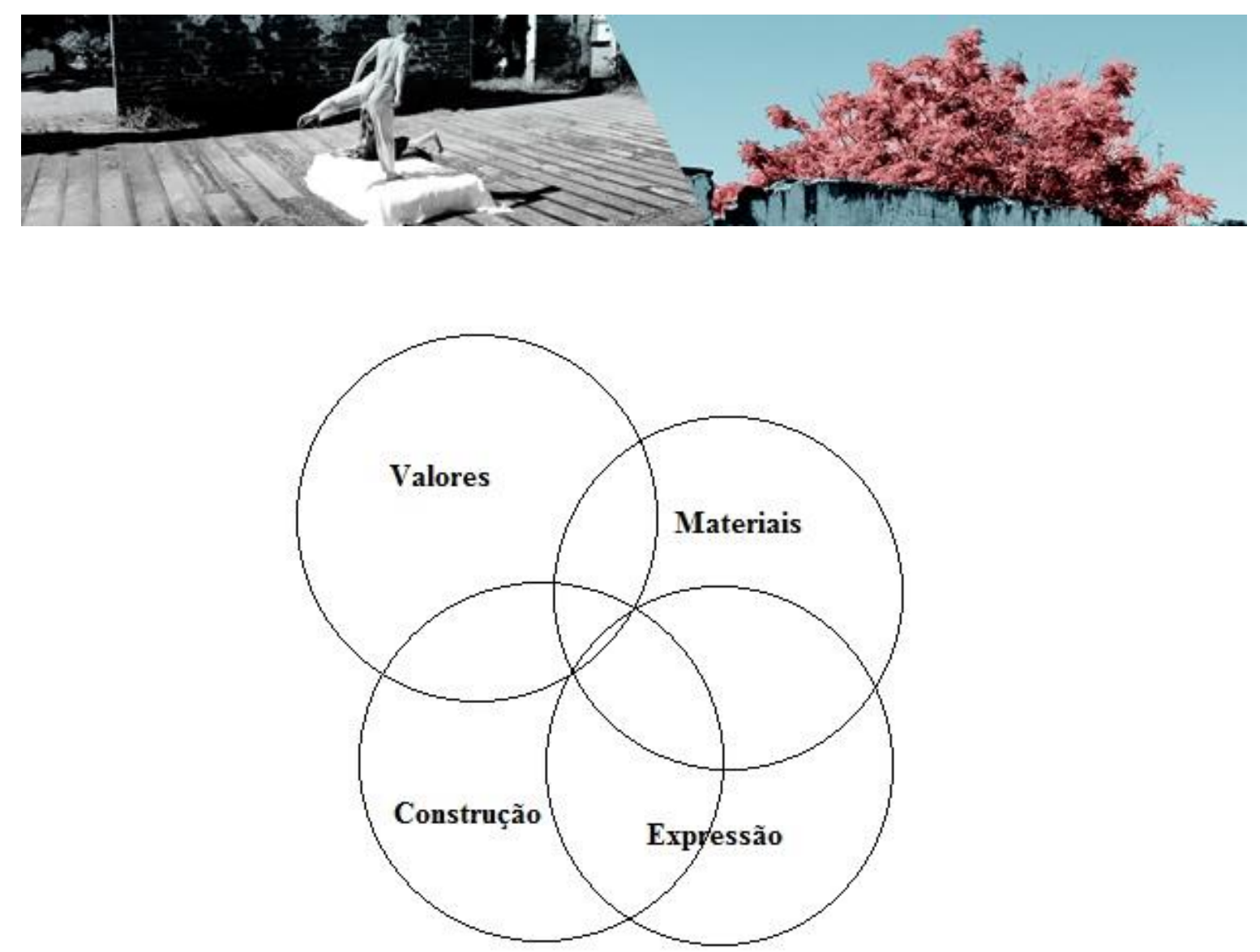

Figura 2: A ausência do domínio espiritual. Adaptado e traduzido de Boyce-Tillman (2007, p. 1416).

Neste sentido procurei interagir com meus alunos em seu aprendizado musical não apenas no que se refere a materiais, construção e expressão musicais, mas também no que tange a valores. Para dialogar com eles neste aspecto as nossas conversas sobre memórias musicais pareciam ser uma abordagem interessante. Percebi que em alguns momentos estes encontros entre características musicais e valores se configuravam em suas narrativas, e tínhamos instantes, durante seus relatos, que poderiam ser descritos como Espirituais, neste viés trazido por Boyce-Tillman (2007).

As narrativas geralmente abordaram momentos nos quais a música se tornou significativa. $O$ estudo de tais momentos pôde ser feito através da narrativa de memórias musicais, nas quais as sensações e aprendizados da experiência dessas situações são traduzidas num contar no qual a pessoa narra sobre a sua relação com um determinado repertório musical. O modo como se aborda a autoformação dos acadêmicos de dança nesta proposta se utiliza do estudo desses momentos

TEIXEIRA, Ziliane Lima de Oliveira; LOURO-HETTWER, Ana Lúcia de Marques. Momentoscharneiras e memórias musicais: encontros e conexões nas narrativas de acadêmicos em dança. Revista da FUNDARTE, Montenegro, p.506-527, ano 19, no 37, Janeiro/Março.

Disponível em: http://.seer.fundarte.rs.gov.br/index.php/RevistadaFundarte/index> 30 de março de 2019. 


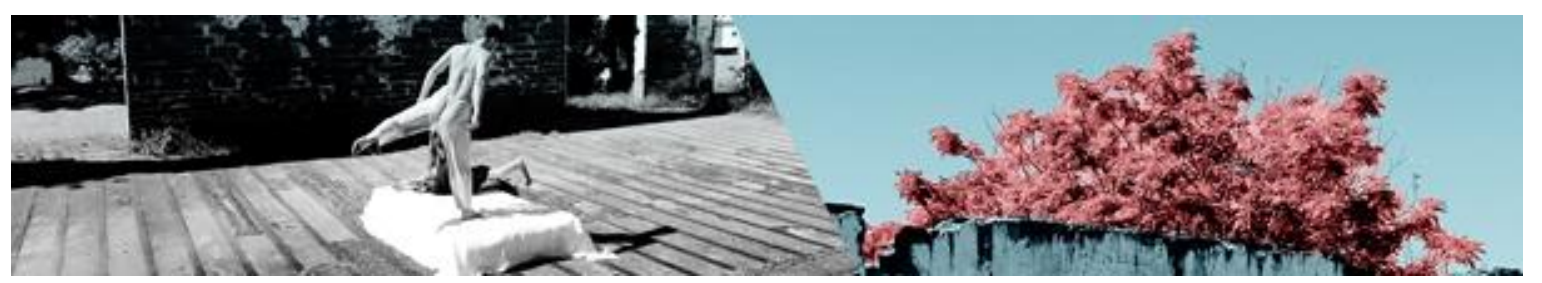

especiais através da "narrativa de si". Neste viés os "momentos" que para Snowder (2007) seriam estudados por um olhar de "conexões" e para Boyce-Tillman (2007) por um olhar de "encontros" são abordados pela ótica dos "momentos-charneira" trazidos por Josso $(1988,2004)$. Assim, mesmo sendo teorias diferentes, traço uma aproximação entre elas para estudar com meus alunos seus encontros e conexões espirituais, embebidos de música dentro de um narrar autoformativo, no qual dialogo com os escritos de Josso. Tomo esta liberdade por localizar nos escritos dessa última autora, uma busca também pela discussão dos aspectos relacionados à espiritualidade, como ela pondera sobre seu próprio silêncio sobre o tema:

\begin{abstract}
Então, por que esse silêncio? Eu priorizo, nesta pesquisa, trabalhar mais particularmente com as dialéticas teoria/prática, de um lado, e práticas individuais/práticas coletivas de conhecimento, de outro. Ora, os materiais empíricos que eu acumulei sobre a dimensão espiritual da formação são insuficientes em qualidade para cotizá-los com minha prática teórica. Portanto, foi preciso omitir-me sobre um aspecto de meu projeto de conhecimento que era, contudo, muito caro. Dito isso, a dimensão espiritual da formação continua, a meu ver, indispensável desde que se postula a ideia de que o que faz o humano - ou, se preferir, a autoproclamação de nossa humanidade - está numa transformação consciencial provocada pela tensão entre meu ser separado e distinto no espaço-tempo cultural e a dimensão cósmica de meu ser. Portanto, é na continuação de meus trabalhos que este silêncio poderá ser preenchido. (JOSSO, 2010, p.78).
\end{abstract}

\title{
Da música para a dança - a música da minha vida
}

Essa pesquisa foi desenvolvida com vinte e dois alunos de Bacharelado e Licenciatura em Dança de uma universidade pública no sul do Brasil, dentro da disciplina Música I, durante o primeiro semestre de 2013.

O trabalho proposto aos alunos era que escolhessem uma música que tivesse relação com a dança, com algum momento do passado ou com o momento em que estavam vivendo; aquela que fosse "a música" da vida deles, que os inspirasse e que fizesse parte da história de suas vidas. A importância de evocar estas recordações e organizá-las em uma narrativa coerente em torno de um tema é muito bem explicitada por Josso (2004).

TEIXEIRA, Ziliane Lima de Oliveira; LOURO-HETTWER, Ana Lúcia de Marques. Momentoscharneiras e memórias musicais: encontros e conexões nas narrativas de acadêmicos em dança. Revista da FUNDARTE, Montenegro, p.506-527, ano 19, oㅜ 37, Janeiro/Março.

Disponível em: http://.seer.fundarte.rs.gov.br/index.php/RevistadaFundarte/index> 30 de março de 2019. 


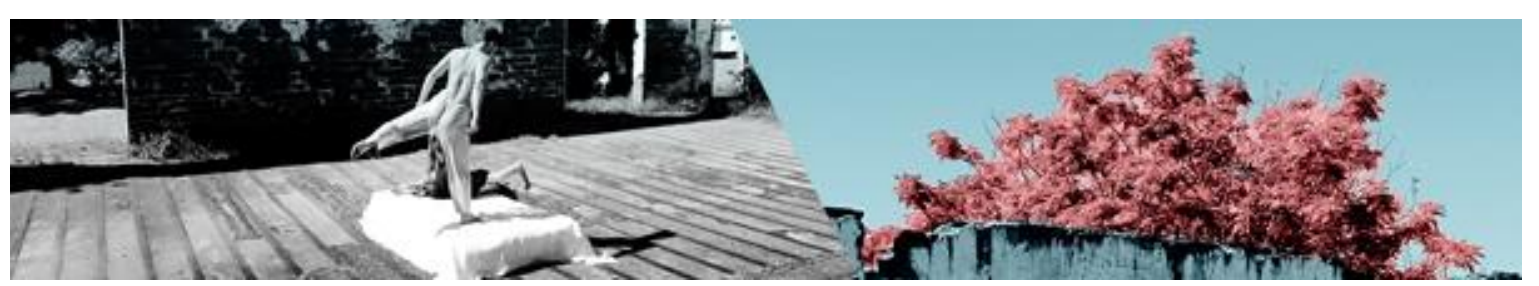

$\mathrm{Na}$ disciplina de Música daquele semestre os alunos dos cursos de dança apresentaram a música escolhida e falaram sobre ela. Ao final do semestre, entregaram esta mesma narrativa por escrito contando a história, que já havia sido relatada em aula, para poder se utilizar nesta pesquisa. Semelhantemente à pesquisa realizada por Torres (2008), nas narrativas dos alunos estão contidas memórias musicais da infância, adolescência e de alguns, da vida adulta, buscando alguma relação com dança na vida deles.

Josso (2004) revela a importância de a narrativa oral ser posteriormente escrita. No momento em que a história é narrada oralmente, existe uma facilidade em relatar o vivido com as palavras para quem está escutando. Por outro lado, a passagem para a narrativa escrita é um processo solitário, que "parece reintroduzir a opacidade no pensar nossa história" (p. 173, grifo da autora). A narrativa oral admite uma objetivação inicial, enquanto a narrativa escrita fornece momentos de autorreflexão, pois existe um distanciamento do olhar sobre si mesmo. Além disso, "a narrativa escrita constitui um suporte particularmente adequado para a pesquisa" (p. 184), sendo fundamental para a realização da minha.

Selecionei alguns fragmentos das narrativas de cinco alunos, no sentido de ressaltar e analisar aspectos que envolvem as lembranças entre música e dança, que representam momentos-charneiras nas suas vidas, nomeadamente uma coreografia premiada, a última coreografia no ensino médio, a superação após a morte de um amigo e o sonho e a realização de cursar a faculdade de dança.

\section{ANÁLISE DE DADOS}

As cinco narrativas que escolhi trazer neste artigo relatam momentos muito significativos no percurso da vida dos acadêmicos, chamados por Josso (1988, 2004) de momentos-charneira.

Quando comecei a analisar as narrativas, pensava somente em fazer uma relação das lembranças entre música e dança. Porém, aos poucos, fui percebendo o

TEIXEIRA, Ziliane Lima de Oliveira; LOURO-HETTWER, Ana Lúcia de Marques. Momentoscharneiras e memórias musicais: encontros e conexões nas narrativas de acadêmicos em dança. Revista da FUNDARTE, Montenegro, p.506-527, ano 19, no 37, Janeiro/Março.

Disponível em: http://.seer.fundarte.rs.gov.br/index.php/RevistadaFundarte/index> 30 de março de 2019. 


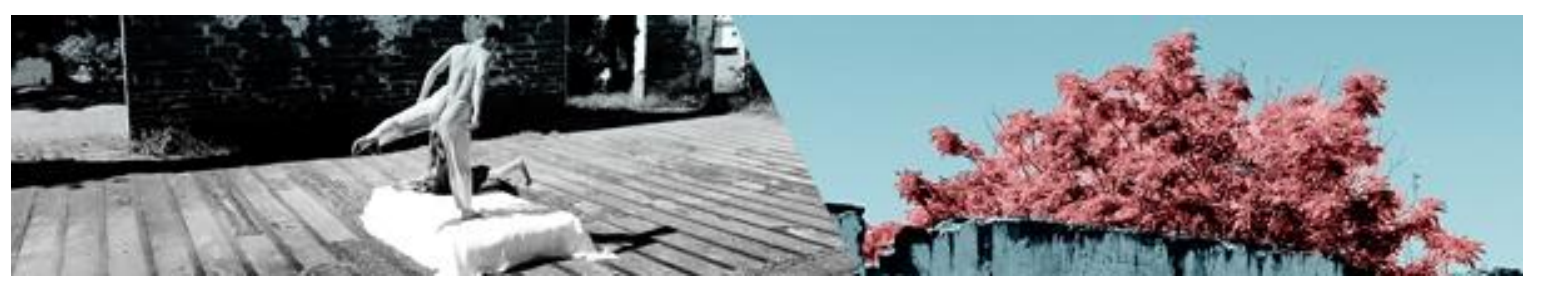

significado que estas músicas tinham na vida deles, e que elas faziam parte de verdadeiros momentos-charneiras, como um marco em suas vidas.

Segundo Josso, esses momentos ou acontecimentos são "aqueles que representam uma passagem entre duas etapas da vida, um 'divisor de águas' [...], uma dobradiça, algo que, portanto, faz o papel de uma articulação" (2004, p. 64).

Nestes momentos-charneira, o sujeito confronta-se consigo mesmo. A descontinuidade que vive impõe-lhe transformações mais ou menos profundas e amplas. Surgem-lhe perdas e ganhos e, nas nossas interações, interrogamos o que o sujeito fez consigo próprio ou o que de si mesmo para se adaptar à mudança, evitá-la ou repetir-se na mudança. (JOSSO, 1988, p. 44).

Estes são momentos onde pessoas conseguem reorientar seu comportamento, pensamento, ambiente, modo de ser e agir. Momentos que podem estar relacionados a situações boas ou ruins, momentos de conflitos e transformações.

\section{Procedimentos}

A partir do conceito de momento-charneira, incluí também, na análise, as concepções de conexões e encontros trazidas pelas abordagens de Educação Musical e Espiritualidade. Assim, começando com uma primeira leitura dos dados, deixei emergir aqueles que se relacionavam com estes conceitos e concepções, sem deixar de considerar também aqueles que me surpreendiam e traziam novas perspectivas. Fundamentei esta visão de análise nos princípios trazidos por Mayring (2000), seguindo na mesma direção das análises de outros trabalhos com abordagens (auto)biográficas que temos realizado no grupo de pesquisas. Tomamos a abordagem da "análise de conteúdo"7 segundo Mayring, considerando que, em

\footnotetext{
7 Tanto em inglês como em português, análise qualitativa de conteúdo é um termo amplamente utilizado em muitas áreas, neste caso o autor não se refere ao que tradicionalmente conhecemos por análise de conteúdo, mas a ideia geral de que o conteúdo de uma narrativa deve ser analisado através de categorias que emergem de sua análise e são novamente testadas em um processo cíclico.
}

TEIXEIRA, Ziliane Lima de Oliveira; LOURO-HETTWER, Ana Lúcia de Marques. Momentoscharneiras e memórias musicais: encontros e conexões nas narrativas de acadêmicos em dança. Revista da FUNDARTE, Montenegro, p.506-527, ano 19, no 37, Janeiro/Março.

Disponível em: http://.seer.fundarte.rs.gov.br/index.php/RevistadaFundarte/index> 30 de março de 2019. 


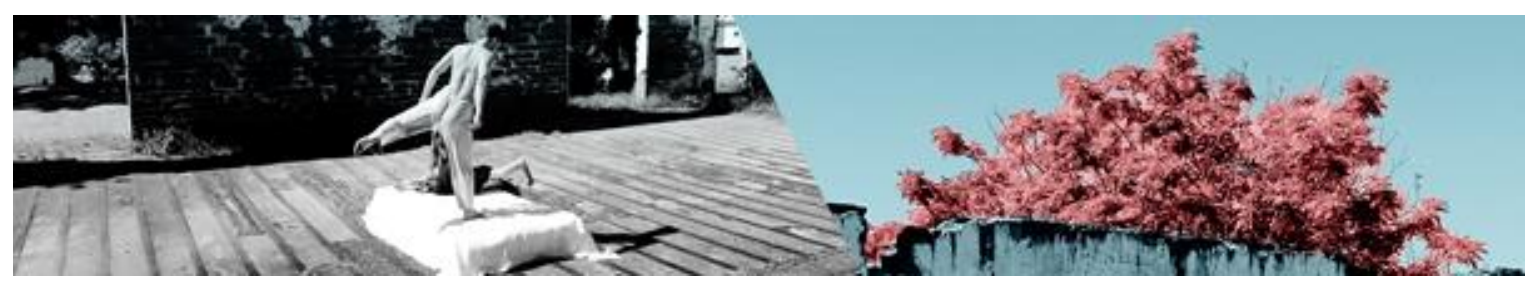

uma análise qualitativa, existe a possibilidade do uso de uma mesma categoria na análise dos dados de diferentes participantes da pesquisa. Como o autor aponta:

[...] dentro do enquadramento das abordagens qualitativas será de interesse central desenvolver os aspectos da interpretação, das categorias, o mais próximo possível dos dados. Dentro do escopo da análise qualitativa de conteúdo foram desenvolvidos procedimentos do desenvolvimento indutivo de categorias de analise que são orientados por processos redutivos formulados dentro da psicologia do processamento textual. (2000, p. 1).

Assim, as análises de dados são feitas por indução e proximidade dos dados, com as categorias emergindo de uma narrativa e a partir desta, procurando encontrar estas categorias nas demais narrativas, transversalizando os dados, de um para outro sujeito da pesquisa, sempre levando em conta o contexto de cada entrevistado.

Esse processo descrito por Mayring não suprime a intuição e a criatividade, mas coloca um direcionamento de rigor, apontando passos que devem ser dados pelo pesquisador:

Com a análise qualitativa de conteúdo nós queremos descrever os procedimentos da análise sistemática de texto, que tentam preservar os pontos fortes de análise de conteúdo em ciências da comunicação (referencial teórico, modelos passo a passo. modelos de comunicação, categorias de condução, os critérios de validade e confiabilidade) para o desenvolvimento de procedimentos qualitativos (desenvolvimento de categorias indutivas, sumarizando, análise de contexto, aplicação de categorias dedutivas), que são metodologicamente controladas. Esses procedimentos permitem uma conexão com etapas de análise quantitativa que pareça significativa para o pesquisador. (MAYRING, 2000, p. 6).

Considero ainda essa citação de Gibbs que vem muito ao encontro da maneira como analisei os escritos dos alunos:

A análise de narrativas e biografias acrescenta uma nova dimensão à pesquisa qualitativa, concentrando-se não apenas no que as pessoas disseram e em coisas e eventos que descreveram, mas na forma como fizeram, por que o disseram e o que sentiram e vivenciaram. Sendo assim, as narrativas possibilitam compartilhar o sentido que a experiência tem para

TEIXEIRA, Ziliane Lima de Oliveira; LOURO-HETTWER, Ana Lúcia de Marques. Momentoscharneiras e memórias musicais: encontros e conexões nas narrativas de acadêmicos em dança. Revista da FUNDARTE, Montenegro, p.506-527, ano 19, oㅜ 37, Janeiro/Março.

Disponível em: http://.seer.fundarte.rs.gov.br/index.php/RevistadaFundarte/index $>30$ de março de 2019. 


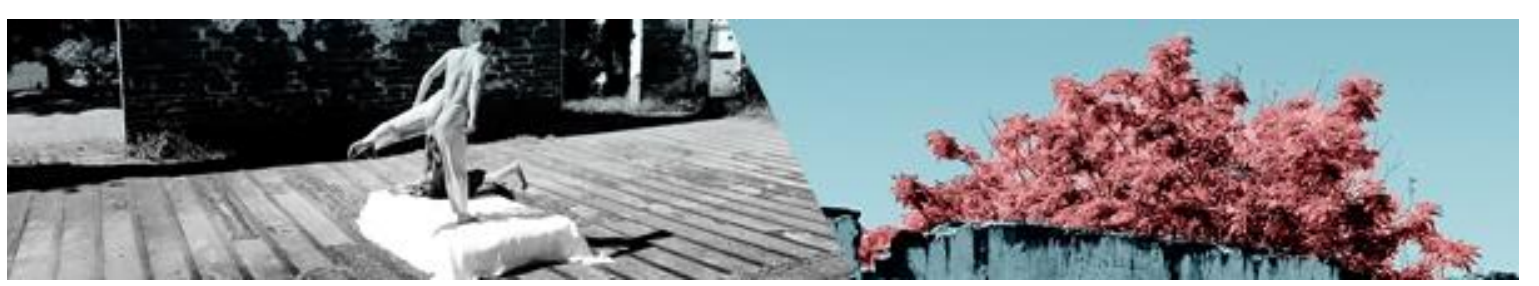

os entrevistados e lhes dar uma voz para que possamos vir a entender de que forma eles encaram a vida. (GIBBS, 2009, p. 95).

\section{Da tela do vídeo game para os palcos}

Minha música escolhida foi a trilha de um jogo de vídeo game, a trilha sonora do SUPER MÁRIO BROS.

Essa trilha fez e ainda faz parte da minha vida. Obviamente comecei a ouvila quando pequeno, pois era um fiel gamer e jogava todos os dias em meu Super Nintendo, portanto, desde a minha infância.

O bacana desta história é que depois de já ter começado a dançar e coreografar tive a ótima ideia de fazer um tributo ao jogo, dançando-o, na época com um parceiro de dança. Com essa coreografia fomos competir em diversos festivais de dança, tais como: Santa Maria em Dança, Santa Rosa em Dança, Santo Ângelo em Dança e em todos felizmente saímos vitoriosos. No decorrer das premiações tivemos a ideia de mandar a gravação da coreografia, de modo que fosse aprovada para permitir que competíssemos no Festival de Dança de Joinville. Fomos aprovados e melhor que isso, ainda ganhamos o festival. [...] Fomos ainda convidados para participar de um programa de uma emissora de TV e passamos para a segunda fase. Tudo isso conquistado junto a trilha do game.

Não ganhamos o programa, mas tudo isso para mim foi uma experiência, um salto profissional inimaginável que me marcou muito, por isso de minha escolha no qual acredito que tenha sido a melhor dentre as tantas músicas já escutadas. (Pedro).

A narrativa de Pedro relata o quanto a trilha sonora de um vídeo game foi importante na vida de dele. Fica muito claro que sua vida profissional como dançarino se divide em antes e depois desta coreografia, sendo esta música parte do seu grande momento-charneira, o divisor de águas, tal como destaca Josso (2004).

\section{"A tal da Wannabe"}

A última coreografia realizada no ensino médio em (apenas) uma gincana escolar - diferente de uma competição famosa como o Festival de Dança de Joinville, onde Pedro conquistou o primeiro lugar -, essa música tem um significado muito especial para Cristina, pois marca a mudança da sua vida, de adolescente

TEIXEIRA, Ziliane Lima de Oliveira; LOURO-HETTWER, Ana Lúcia de Marques. Momentoscharneiras e memórias musicais: encontros e conexões nas narrativas de acadêmicos em dança. Revista da FUNDARTE, Montenegro, p.506-527, ano 19, oㅜ 37, Janeiro/Março.

Disponível em: http://.seer.fundarte.rs.gov.br/index.php/RevistadaFundarte/index> 30 de março de 2019. 


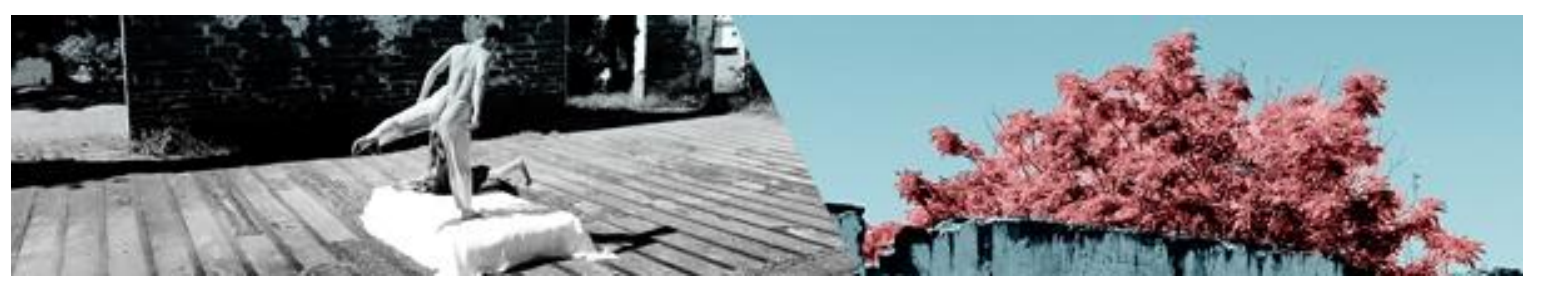

para adulta, do ensino médio para o ensino superior: o início da sua carreira profissional como bailarina.

Escolhi Wannabe, das Spice Girls, mas não pelo estilo da música, nem pela letra. Escolhi porque essa música era uma das minhas trilhas sonoras para minhas mini coreografias limitadas pelo tamanho da sala de casa, entre o sofá e a TV.

Quando eu cheguei ao terceiro ano do ensino médio, já estava com a ideia fixa que iria fazer faculdade de dança. Eu sempre fui a bailarina da turma, que ficava piruetando em qualquer lugar da escola e sempre que tinha algum trabalho relacionado à dança eu me metia no meio. E nesse ano teria a gincana do colégio e uma das provas era criar uma dança. Eu estava com milhões de ideias, mas tive uma surpresa quando um dos meus colegas sugeriu a música e todo mundo aprovou: a tal da Wannabe. (Cristina).

\section{Superando uma perda: "infelizmente ficou só em nossos planos"}

Muitas vezes os alunos se emocionavam ouvindo as narrativas dos colegas. Sentimentos de saudade, de alegria e também de tristeza. Dois alunos apresentaram músicas relacionadas com a perda de um amigo. Um destes alunos foi Clarice, que apresentou uma música em que foi coreógrafa com um colega que veio a falecer pouco tempo depois. O desejo que tinham de continuar coreografando trilhas sonoras ficou apenas em planos.

Lembro vagamente que fui participar da minha primeira audição de Ballet e lá estava ele, sempre comigo [...] Como tínhamos gostos parecidos resolvemos coreografar a trilha do filme Dirty Dancing Ritmo Quente The time of my life (Donald Markowitz). E até ali eu tinha dançado somente Ballet. Quando começamos o trabalho coreográfico me encantei pela dança de salão, fizemos um trabalho árduo e cansativo, nos dedicamos de corpo e alma para aquele objetivo ser alcançado e foi com muito sucesso. No dia de nossa amostra de trabalhos dançamos a coreografia "NOSSO CORPO", depois de vermos que deu certo, resolvemos coreografar somente trilhas sonoras de filmes, mas infelizmente ficou só em nossos planos. [...] Depois que o perdi fiquei um ano e meio sem dançar, até que um dia parece que uma voz sussurrou pra mim dizendo "Por que você parou? Você é única! Dance pelo o que sempre acreditou! Dance por você, mas também dance por MIM'! (Clarice)

TEIXEIRA, Ziliane Lima de Oliveira; LOURO-HETTWER, Ana Lúcia de Marques. Momentoscharneiras e memórias musicais: encontros e conexões nas narrativas de acadêmicos em dança. Revista da FUNDARTE, Montenegro, p.506-527, ano 19, oㅜ 37, Janeiro/Março.

Disponível em: http://.seer.fundarte.rs.gov.br/index.php/RevistadaFundarte/index> 30 de março de 2019. 


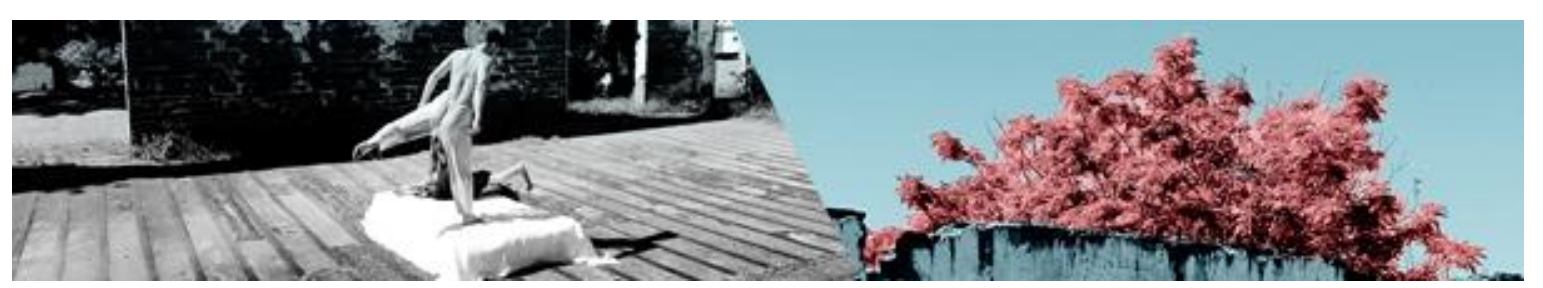

Essa música estará para sempre marcada na vida de Clarice. Não como a boa lembrança de Pedro ou Cristina, mas com a saudade e a dor da perda. Após um tempo sem dançar, quase desistindo de seu sonho, ela decide retomar seu caminho, reorientar sua vida e sua relação com a dança. Momentos que ficaram marcados em sua vida.

\section{"Eu quero ser feliz agora”}

Antes da existência dos cursos de Bacharelado e Licenciatura em Dança nesta Universidade, bailarinos desta cidade e região frequentavam outros cursos de graduação. Na primeira turma dos cursos de Dança haviam alunos já formados em outros cursos ou que trocaram de cursos, oriundos da Educação Física, Biologia, Comunicação Social, Jornalismo, dentre outras. Com a criação do novo curso, o desejo de mudar e voltar a dançar se misturaram com o medo e a insegurança do novo futuro.

A letra da canção é extremamente simples e fala sobre coisas essenciais como amor, tranquilidade, fé e desapego material. Por gostar muito dela, passei a ouvi-la com frequência e, quando estava cursando a graduação em Comunicação Social e percebi que não era a profissão que eu gostaria de exercer durante o resto da minha existência, fiquei muito angustiada. Nessa época, as frases do refrão de Simple Man ficavam repetindo-se na minha mente: "E seja um homem simples; seja algo que você ame e entenda". E assim eu tive certeza de que precisava voltar ao plano de estudar dança, porque sempre foi algo que eu amo e compreendo, e dessa forma tive coragem de iniciar a minha profissionalização na área. (Priscila)

A letra dessa música (Eu quero ser feliz agora) fala de sonhos, da busca incessante da felicidade. Naquele momento da minha história marcou profundamente, pois estava passando por um momento de introspecção e reflexão (a crise dos quarenta anos de idade...), de rever o que já havia concretizado até então, e os sonhos que ainda desejava realizar. Dentre esses sonhos estava estudar a dança, surgiu à oportunidade de fazer o vestibular na UFSM, só faltava coragem. Encarar uma turma onde a maioria dos colegas provavelmente seria adolescente me assustava. O medo de que o corpo não respondesse as atividades práticas propostas, a falta de disponibilidade de horários, enfim, as inseguranças eram muitas. Nos momentos de desânimo, muitas vezes escutei essa música e, motivada, retomei a busca do meu sonho, que a cada aula do curso está sendo consumado. (Aline)

TEIXEIRA, Ziliane Lima de Oliveira; LOURO-HETTWER, Ana Lúcia de Marques. Momentoscharneiras e memórias musicais: encontros e conexões nas narrativas de acadêmicos em dança. Revista da FUNDARTE, Montenegro, p.506-527, ano 19, ํㅡ 37, Janeiro/Março.

Disponível em: http://.seer.fundarte.rs.gov.br/index.php/RevistadaFundarte/index $>30$ de março de 2019. 


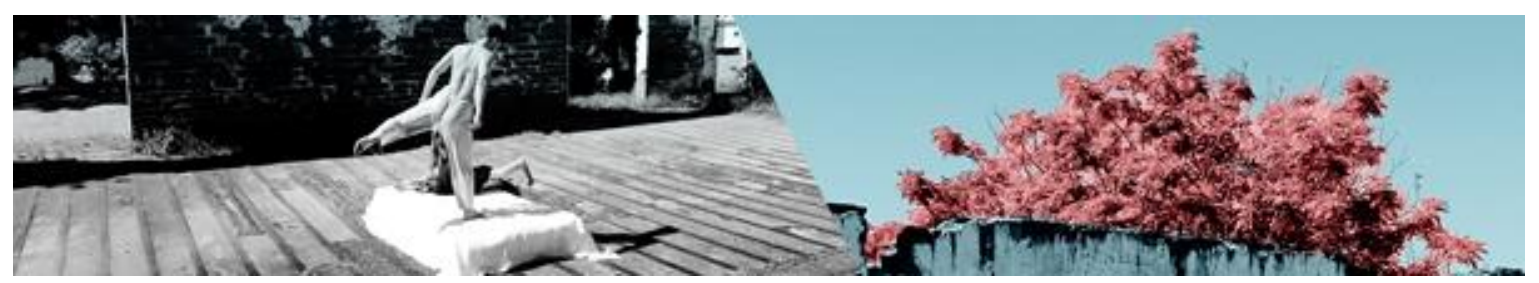

Priscila trocou de curso. A letra da música, que são conselhos das mães e avós dos compositores, se assemelhava aos conselhos que a mãe de Priscila deu a ela em um período em que esteve doente e temia deixá-la órfã: seja um homem simples.

Mas para Aline não era tão simples. Ela já tinha cerca de 40 anos. Mãe de três filhas, cursando um mestrado, com um emprego público na área da saúde. $\mathrm{O}$ medo de passar por uma graduação outra vez com colegas bem mais jovens, o receio do corpo talvez não responder às práticas e a falta de horários livres eram algumas de suas inseguranças. Porém, isso mudou a partir do momento que escutou a música Eu quero ser feliz agora, de Oswaldo Montenegro, e assistiu ao clipe - que não é o clipe oficial da música ${ }^{8}$ - no qual a bailarina trabalha em um bar cujo dono não a permite dançar, até o momento em que ela quebra um copo e decide correr até uma academia de dança e entregar-se ao seu sonho. Aline, então, tomou coragem e fez o vestibular, retomou a busca de seu sonho e tem se realizado a cada aula. A mensagem que ela passou para todos na turma no dia de sua apresentação foi esta: não adie seus sonhos, seja feliz agora!

Além destas alunas, outros alunos cujas narrativas não estão presentes neste texto também destacaram músicas que se tornaram o grande impulso para decisão de seguir na carreira como dançarino e cursar a faculdade de Dança. Músicas que marcaram suas vidas e os motivaram no momento de reflexão sobre esta decisão.

\section{TRANSVERSALIZAÇÃO DE DADOS E APONTAMENTOS FINAIS}

Todas estas narrativas foram analisadas destacando os momentos-charneira que marcaram as vidas dos alunos de dança da disciplina que ministrei. Além dessa

\footnotetext{
${ }^{8}$ Clipe disponibilizado no link: http://www.youtube.com/watch?v=loQQrTG_wmc
}

TEIXEIRA, Ziliane Lima de Oliveira; LOURO-HETTWER, Ana Lúcia de Marques. Momentoscharneiras e memórias musicais: encontros e conexões nas narrativas de acadêmicos em dança. Revista da FUNDARTE, Montenegro, p.506-527, ano 19, ํㅡ 37, Janeiro/Março.

Disponível em: http://.seer.fundarte.rs.gov.br/index.php/RevistadaFundarte/index> 30 de março de 2019. 


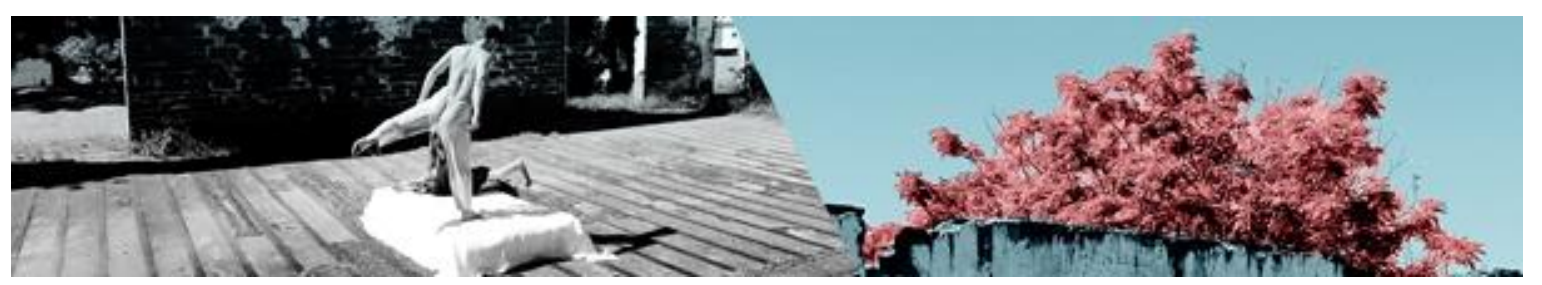

lente teórica baseada em Josso $(1988,2004)$ também me aproximo dos relatos pelos viés da Espiritualidade e Arte, no qual destaco a ideia das conexões trazida por Snowber (2007) e dos encontros destacados por Boyce-Tillman (2007).

\section{Conexões, encontros e momentos-charneira}

Para Snowber (2007) a experiência espiritual está ligada a uma conexão principalmente da pessoa consigo mesma. Se tomarmos pequenos trechos das narrativas dos alunos, vemos como a tarefa de falar sobre uma música importante em suas vidas parece conduzi-los a uma conexão consigo mesmo. "Tudo isso para mim foi uma experiência, um salto profissional inimaginável que me marcou muito" (Pedro). Pedro se conecta com a reflexão sobre ele próprio enquanto profissional antes e depois, localizando esse momento como marcante em sua carreira. Já para Cristina, ela diz: "sempre fui a bailarina da turma, que ficava piruetando em qualquer lugar da escola, e sempre que tinha algum trabalho relacionado à dança eu me metia no meio". Ela entra em sintonia com as suas vivências de infância para localizar a sua "vocação" profissional em sua história de vida. Para Priscila, estudar dança se relaciona com os valores da música "Simple Man" que são os que ela também destaca como importantes para si mesma. Já Aline relaciona a música "Eu quero ser feliz agora" com a superação das inseguranças e do desânimo e acrescenta "retomei a busca do meu sonho, que a cada aula do curso está sendo consumado" (Aline). Desta maneira as músicas são instrumentos com os quais os alunos fazem reflexões sobre as suas "conexões" consigo próprios.

Os encontros que para Boyce-Tillman (2007, p. 1416) são "encontro com o Outro na música" também estão presentes principalmente nas parcerias para a coreografia, nos colegas de colégio que definem a aluna como bailarina, nas pessoas presentes ou não na narrativa, que auxiliam a escolha profissional pelo curso de dança e na amizade tão profunda que continua falando a sua reflexão mesmo depois da morte do companheiro:

TEIXEIRA, Ziliane Lima de Oliveira; LOURO-HETTWER, Ana Lúcia de Marques. Momentoscharneiras e memórias musicais: encontros e conexões nas narrativas de acadêmicos em dança. Revista da FUNDARTE, Montenegro, p.506-527, ano 19, no 37, Janeiro/Março.

Disponível em: http://.seer.fundarte.rs.gov.br/index.php/RevistadaFundarte/index> 30 de março de 2019. 


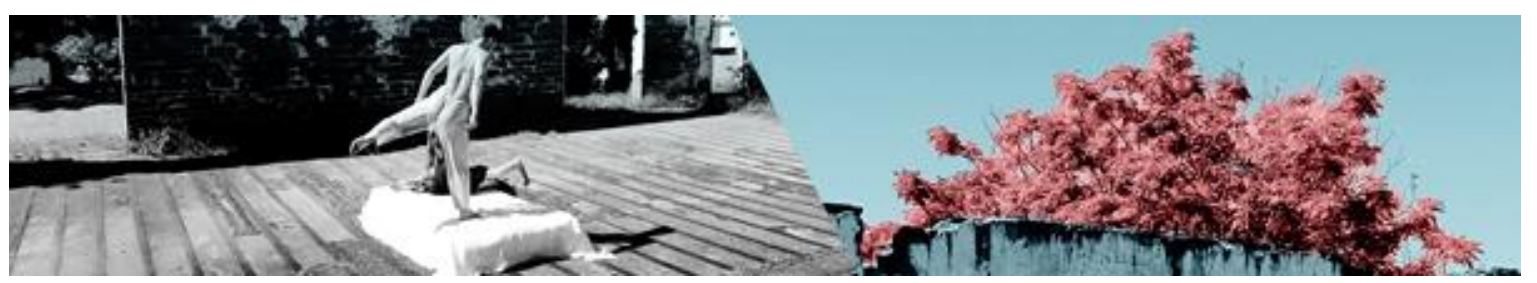

Depois que eu o perdi fiquei um ano e meio sem dançar, até que um dia parece que uma voz sussurrou pra mim dizendo "Por que você parou? Você é única! Dance pelo o que sempre acreditou! Dance por você, mas também dance por MIM'! (Clarice).

Assim estes momentos-charneiras, que apontam uma virada na vida desses alunos de dança, estão repletos de conexões consigo próprios e encontros com os outros. Através do estudo da disciplina de Música utilizando a narrativa oral e escrita dessas histórias, me aproximei, por um lado, de Josso (1988, 2004), ao convidar os alunos a falarem e escreverem sobre momentos importantes que envolveram música em suas vidas, bem como da perspectiva da Espiritualidade e das Artes, ao tratar das relações nessas histórias dos alunos consigo mesmos e com os outros através das músicas.

\section{Algumas considerações}

Não tenho certeza se esses alunos já tinham percebido a importância dessas músicas nas suas vidas, até o momento de se narrarem na disciplina. Alguns talvez sim. Mas outros parecem ter se dado conta na hora da busca pela música do real significado para eles.

$\mathrm{Na}$ disciplina busquei trabalhar uma abordagem de ensino de música que vai além dos materiais, construção e expressão, incluindo também os valores. Essas dimensões na proposta que abordei estão integradas dentro de um olhar de Educação Musical e Espiritualidade (BOYCE-TILLMAN, 2007). Para tanto, me utilizei de memórias musicais em um viés semelhante ao adotado por Torres (2008). Ao analisar as memórias musicais relatadas pelos acadêmicos de dança escolhi a perspectiva dos momentos-charneiras de Josso $(1988,2004)$.

A partir do momento-charneira o sujeito passa por uma reorientação na sua maneira de pensar o seu meio e de pensar em si (JOSSO, 1988). Para estes alunos, a música faz parte de uma vitória, de uma passagem de um tempo para outro, de um recomeço, de uma mudança, de uma nova chance de ser feliz. Assim, estudar

TEIXEIRA, Ziliane Lima de Oliveira; LOURO-HETTWER, Ana Lúcia de Marques. Momentoscharneiras e memórias musicais: encontros e conexões nas narrativas de acadêmicos em dança. Revista da FUNDARTE, Montenegro, p.506-527, ano 19, no 37, Janeiro/Março.

Disponível em: http://.seer.fundarte.rs.gov.br/index.php/RevistadaFundarte/index> 30 de março de 2019. 


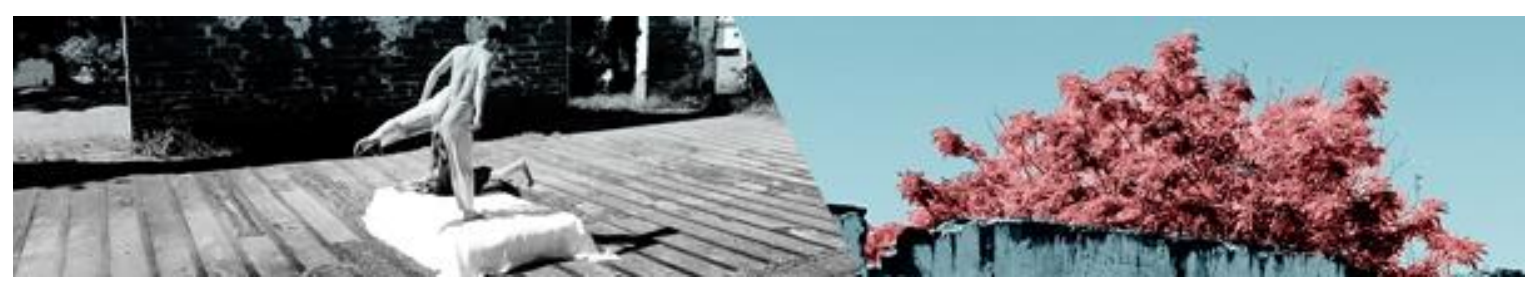

música para os meus alunos não foi apenas se aproximar de uma linguagem em sons, mas de múltiplas conexões e encontros entre as pessoas e as músicas, ampliando a ementa original da disciplina sem deixar de trabalhar os aspectos rítmicos originalmente propostos. Esta experiência soma-se aos esforços que temos feito entre os docentes universitários do grupo de pesquisas, de conjugar abordagens de Educação Musical e perspectivas (auto)biográficas nas nossas práticas do ensino superior e de pesquisa. Nessa direção pretendemos contribuir para os debates sobre formação de artistas e professores capazes de refletir sobre suas práticas.

Ouvir nos últimos dias de aula os alunos contarem que essa atividade, que no início pareceu ser tão simples - uma memória musical - despertou-lhes tantos sentimentos, proporcionou-Ihes conhecer uns aos outros e reconhecerem a si mesmo. O sentimento de gratidão deles por esta atividade, por perceberem a importância e ligação entre música e dança, o reconhecimento dos momentoscharneira em suas vidas, foi um dos melhores momentos enquanto docente desta disciplina. Momentos de trocas, de aprendizagens, de formação, de autoformação, de sentimentos, de alma, de música, de ritmo, de dança.

\section{Referências:}

ALVES, Nilda. Dois fotógrafos e imagens de crianças e seus professores: as possibilidades de contribuição de fotografias e narrativas na compreensão de espaços-tempo de processos curriculares In: OLIVEIRA, Inês Barbosa (Org.) Narrativas: outros conhecimentos, outras formas de expressão. Rio de Janeiro: DP et alii; FAPERJ, 2010, p. 185-206.

BOWMAN, Wayne D. Why Narrative? Why Now? Research Studies in Music Education, n. 27, p. 5-20, 2006.

BOYCE-TILLMAN, June. Spirituality in the Musical Experience. In. BRESLER, Liora (Ed.) International Handbook of Research in Arts Education. Dordrecht: Springer, 2007, p. 1405-1422.

TEIXEIRA, Ziliane Lima de Oliveira; LOURO-HETTWER, Ana Lúcia de Marques. Momentoscharneiras e memórias musicais: encontros e conexões nas narrativas de acadêmicos em dança. Revista da FUNDARTE, Montenegro, p.506-527, ano 19, no 37, Janeiro/Março.

Disponível em: http://.seer.fundarte.rs.gov.br/index.php/RevistadaFundarte/index> 30 de março de 2019. 


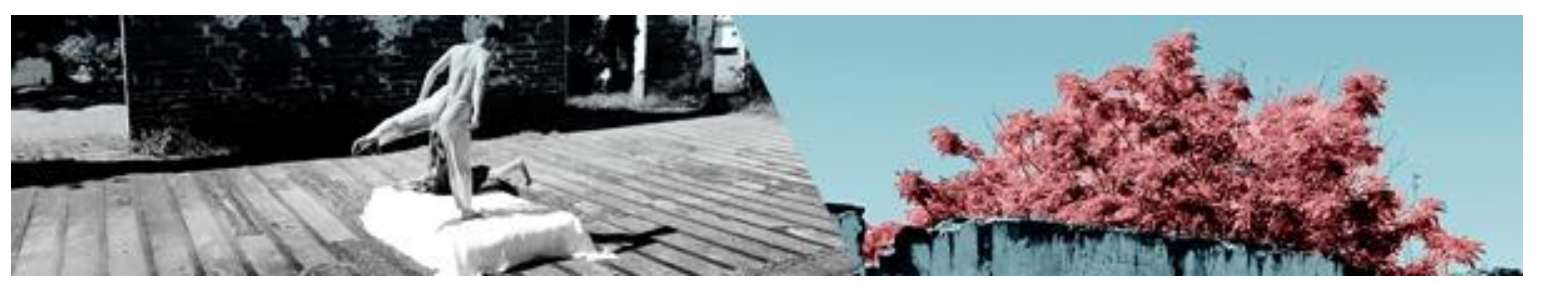

BRESLER, Liora. Embodied Narrative Inquiry: A Methodology of Connection. Research Studies in Music Education, n. 27, p. 21-43, 2006.

CONNELLY, Michael F.; CLANDININ, Jean D.; HE, Ming Fang. Teachers' personal practical knowledge on the professional knowledge landscape. Teaching and Teacher Education, v. 13, n. 7, p. 665-674, 1997.

DOSSÊ, François. O Desafio Biográfico: escrever uma vida. Tradução de Gilson César Cardoso de Souza. São Paulo: Editora da Universidade de São Paulo, 2009.

GIBBS, Graham. Análise de Dados Qualitativos. Tradução de Roberto Cataldo Costa. Porto Alegre: ARTMED, 2009.

JOSSO, Marie Christine. Da Formação do sujeito... ao sujeito da formação. In: NÓVOA, António; FINGER, Mathias. O método (auto)biográfico e a formação. Lisboa: Ministério da Saúde, 1988, p. 35-49.

JOSSO, Marie-Christine. Experiências de vida e formação. Tradução de José Cláudio e Júlia Ferreira. São Paulo: Editora Cortez, 2004.

JOSSO, Marie-Christine. Caminhar para si. Tradução de Albino Pozzer. Porto Alegre: Edipucrs, 2010.

LOURO, Ana Lúcia. Improvisando sobre um tema de Larrosa: diários de aula numa disciplina sobre "narrativas de si" na pesquisa em educação musical. Revista Educere et Educare, n. 16, v. 8, p. 479-497, 2013.

LOURO, Ana Lúcia; TEIXEIRA, Ziliane Lima de Oliveira. A "narrativa de si" na pesquisa em Educação Musical: algumas reflexões a partir de uma disciplina de investigação. In: CONGRESSO NACIONAL DA ABEM, 21. Pirenópolis, 2013. Anais eletrônicos... Pirenópolis: UNB, 2013, p.12-21.

MARYING, Philipp. Qualitative Content Analysis. Forum Qualitative Sozialforschung. v.1, n.2, art. 20, p. 1-7, $2000 . \quad$ Disponível em: http://nbnresolving.de/urn:nbn:de:0114-fqs0002204 Acesso em: 28 nov. 2013.

OLIVEIRA, Valeska F.; OLIVEIRA, Vânia F.; FABRÍCIO, Laura E. O. O oral e a fotografia na pesquisa qualitativa. In: ABRAHÃO, Maria Helena. Menna Barreto (Org). A Aventura (Auto)Biográfica: Teoria e Empiria. Porto Alegre: Edipucrs, 2004.

SMALL, Cristopher. Musicking: A ritual in Social Space. Disponível em <http://jlarrystockton.com/Stocktoj/small.pdts. Acesso em: 09 set. 2014.

TEIXEIRA, Ziliane Lima de Oliveira; LOURO-HETTWER, Ana Lúcia de Marques. Momentoscharneiras e memórias musicais: encontros e conexões nas narrativas de acadêmicos em dança. Revista da FUNDARTE, Montenegro, p.506-527, ano 19, no 37, Janeiro/Março.

Disponível em: http://.seer.fundarte.rs.gov.br/index.php/RevistadaFundarte/index> 30 de março de 2019. 


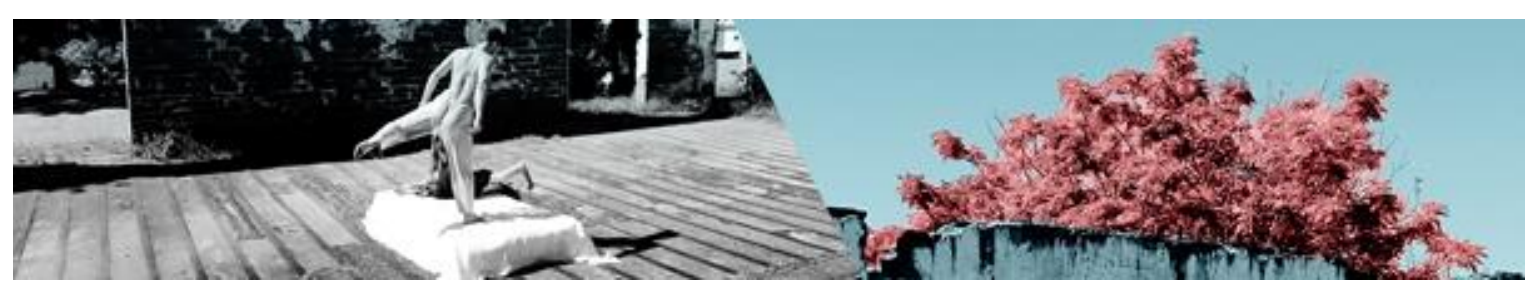

SNOWBER, Celeste N. The Soul Moves: Dance and Spirituality in Educative Practice. In. BRESLER, Liora (Ed.) International Handbook of Research in Arts Education. Dordrecht: Springer, 2007, p. 1449-1456.

STAUFFER, Sandra L.; BARRETT, Margaret S. Narrative Inquiry in Music Education: Toward Resonant Work. In: BARRETT, Margaret S.; STAUFFER, Sandra L. Narrative Inquiry in Music Education: Troubling Certainty. New York: Springer, 2009, p. 19-29.

TORRES, Maria Cecília de Araújo Rodrigues. Músicas do cotidiano e memórias musicais: narrativas de si de professoras do ensino fundamental. In: SOUZA, Jusamara (Org.) Aprender e ensinar música no cotidiano. Porto Alegre: Editora Sulina, 2008, p. 237-258.

TEIXEIRA, Ziliane Lima de Oliveira; LOURO-HETTWER, Ana Lúcia de Marques. Momentoscharneiras e memórias musicais: encontros e conexões nas narrativas de acadêmicos em dança. Revista da FUNDARTE, Montenegro, p.506-527, ano 19, ํㅜ 37, Janeiro/Março.

Disponível em: http://.seer.fundarte.rs.gov.br/index.php/RevistadaFundarte/index> 30 de março de 2019. 